\section{Nutritional evaluation and storage stability of popped pearl millet bar}

\author{
Ritu Singh $^{1,2}$, Karuna Singh ${ }^{1}$ and \\ Manjeet Singh Nain ${ }^{3, *}$ \\ ${ }^{1}$ Amity University, Sector 125, Noida 201 301, India \\ ${ }^{2}$ Subject Matter Specialist (Home Science), \\ Krishi Vigyan Kendra (KVK), Ujwa, Delhi 110 073, India \\ ${ }^{3}$ ICAR-Indian Agricultural Research Institute, \\ New Delhi 110 012, India
}

The study was aimed at making the pearl millet available in ready-to-eat form to people with some enhanced nutritional and storage properties. A bar was developed through popping processing using pearl millet as main ingredient. It was formulated using dry raw materials (popped pearl millet, popped amaranth, puffed bengal gram, flax seeds, sunflower seeds and raisins), and agglutinative ingredients (sugar and carboxy methyl cellulose). The developed bar was evaluated for proximate composition, nutritional quality, as well as change in moisture, water activity $\left(a_{w}\right)$, free fatty acids and peroxide value, textural and sensory attributes, and total microbial load during storage under ambient conditions $\left(25 \pm 28.0^{\circ} \mathrm{C}\right.$ and $65 \pm 10 \%$ RH) after packaging in high density poly ethylene and metalized-polyester polyethylene pouches for 3 months. The developed bar was found to have $10.84 \%$ protein, $4.39 \%$ fat and $6.45 \%$ dietary fibre. The minerals and vitamins like calcium, phosphorus, iron, and zinc estimated, were: $58.70,215.65,3.17$ and $5.13 \mathrm{mg} /$ $100 \mathrm{~g}$ respectively. The metallized pouch film was found suitable for packing popped pearl millet bars with respect to its stability and acceptability, and the product remained chemically and microbiologically safe and stable during entire storage. The development of composite bar using low cost, locally available ingredients were nutri dense and a convenient snack for children and adults.

Keywords: Free fatty acid, nutritional analysis, peroxide value, popped pearl millet bar, sensory evaluation, storage.

PEARL Millet (Pennisetum glaucum) locally known as bajra is an important and widely grown millet in some arid and semi-arid regions of Africa and the Indian subcontinent since pre-historic times. It is a source of feed and fodder for livestock in the rain-fed regions and a staple food for majority of the poor and small land holders of the country. Being C4, it excels all other cereals in photosynthetic efficiency and dry matter production capacity. Pearl millet requires less input, short duration and is considered as nutritious food, feed and fodder. It is usually grown under the most adverse agro-climatic conditions where other crops like sorghum and maize fail to

\footnotetext{
*For correspondence. (e-mail: msnain@gmail.com)
}

produce economic yields. Pearl millet in India, with an average productivity of $1132 \mathrm{~kg} /$ ha during 2015-16 (ref. 1 ), is the third most widely cultivated food crop after rice and wheat, and is grown on 7.128 million ha land. More than $90 \%$ of millet acreage in India is contributed by the major pearl millet growing states like Rajasthan, Maharashtra, Gujarat, Uttar Pradesh and Haryana.

Pearl millet is nutritionally superior to major cereals such as rice and wheat, since it is a good source of carbohydrates, protein, dietary fibre and micronutrients. It is loaded with vitamins, potassium, phosphorus, magnesium, iron, zinc, copper and manganese. The phytochemicals like tannins, phytates present in pearl millet act as antioxidants $^{2}$. It has low glycaemic index, contain small amount of flavonoids and is gluten free. Pearl millet has high level of calcium, iron, zinc, lipids, and amino acids such as lysine, tryptophan, threonine and fatty acids like omega-9, omega-6 and omega-3 (ref. 3).

Even though probability of this millet for development of ready-to-eat food items exists, very little effort has gone on this aspect. Processing of expanded or puffed cereals have been known since several centuries. Methods involving high temperature-short time treatments have been applied to prepare puffed or popped or expanded cereals and legumes. Puffing gelatinizes the starch and produces ready-to-eat products and such products are commonly used as snacks, breakfast food or as main ingredients in snack formulations. Popped cereals or millets are crisp and crunchy foods with desirable aroma and are highly appreciated for their lightness and are adaptable for mixes ${ }^{4,5}$. Processing and product diversification of pearl millet has caught lot of attention recently. Nutritional evaluation of the popped pearl millet showed significant decrease in phytic acid, a major antinutritional factor in pearl millet, and the nutritive popped grain was found to be a very good snack ${ }^{6}$. Like popped rice or corn, popped pearl millet too was found to have potential to be established in the market, especially to derive its nutritional benefits. The exploitation of popped pearl millet for development of ready-to-use products like snack bar may help in increased consumption and thus nutritional security of the consumers.

Cereal based snack bars are small rectangular nutritional food bars with a weight of $25-50 \mathrm{~g}$ and prepared from multiple ingredients including cereals, fruits, nuts, sugar, etc. These days nutritional bars have become popu$\operatorname{lar}^{7,8}$ and exist in several types of cereal based snack bars such as high-protein, high-fibre and high-calorie bars. These bars offer a fast, appropriate food source requiring modest preparation, with long shelf life and no refrigeration requirements. These bars packed in suitable packaging materials like metalized polyester polyethylene (MP), aluminium pouch, vacuum packaging, etc., to protect from the entry of moisture and oxygen during storage, have carbohydrates, protein, fat, fibre, nutraceuticals, preservatives and some functional additives for use as 
normal or special diets. The cereal bars may have different size and shapes like square, rectangular or oval, as well as different methods of processing like extrusion, use of super saturated sugar solution for ingredients binding and high force compression ${ }^{9}$. Depending on the ingredients used, manufacturing of the bar is easy, and can be sold at a low price. Due to growing consumer demand for healthy, nutritious and convenient foods, attempts to improve this millet's nutritional value as snack food by modifying its nutritive composition ${ }^{10}$, are being made for popping of pearl millet grain. Use of grain popping process, makes it practical for human consumption and the grains serve as the base ingredient in the production of snack bars. Hence, the present study was aimed at making the millets available to people in ready-to-eat form with some enhanced nutritional properties.

Pearl millet variety CZP-9802 (Pennisetum glaccum) was collected from Central Arid Zone Research Institute, Jodhpur, India. Grain amaranthus (Amaranthus gangeticus), roasted bengal gram (Cicer arietinum), flax seeds (Linum usitatissimum), sunflower seeds (Helianthus annuus) and other ingredients such as sugar, carboxy methyl cellulose (CMC), and resins were acquired from market. To remove dust and other extraneous materials the dried ingredients were cleaned and stored at room temperature in plastic containers.

Moisture, crude protein, ash, crude fibre and fat contents were estimated by Association of official Agricultural Chemists (AOAC) method ${ }^{11}$. The carbohydrate content was calculated by the difference method. The total calcium, phosphorus, $\mathrm{Fe}$ and $\mathrm{Zn}$ were estimated by Atomic Absorption Photometer ${ }^{11}$. The vitamins E, Niacin and Folic acid were estimated by $\mathrm{AOAC}^{12,13}$. The soluble, insoluble and total dietary fibre were evaluated by American Association of Cereal Chemists (AACC) ${ }^{14}$ and AOAC methods ${ }^{15}$.

The product samples were withdrawn periodically every fifteen days interval and subjected for moisture, free fatty acid (AOAC 2000), peroxide value estimation by the method of Syed et al. ${ }^{16}$. Water activity $\left(a_{\mathrm{w}}\right)$ was measured through ROTRONIC (model Hygro lab 3) instrument under controlled temperature condition and sensory estimation throughout the storage period of 3 months.

The microbial contamination of the bar was determined during storage. The total plate count (TPC) and yeast/ mold count was determined by the method of Olunlade et $a l .{ }^{17}$. The media nutrient agar (NA) was used for TPC, and potato dextrose agar (PDA) for yeast and mold counts. Serial dilutions were made for each sample and one $\mathrm{ml}$ of the appropriate dilution was poured $10^{-2}$ and $10^{-1}$ serial dilution were used for pouring plate in triplicate on selective media. NA media was prepared by weighing $7 \mathrm{~g}$ of nutrient agar media powder into a $500 \mathrm{ml}$ conical flask and dissolving it with $250 \mathrm{ml}$ distilled water. The conical flask was covered with non-absorbent cotton wool plug wrapped with aluminium foil and warmed on a heating mantle for the mixture to homogenize. Thereafter, the content of the flask was sterilized in an autoclave at $121^{\circ} \mathrm{C}$ for $15 \mathrm{~min}$. Preparation of PDA media was done as similar to above described NA media after weighing $9.75 \mathrm{~g}$ of Potato Dextrose agar media powder, into conical flasks. Chloramphenicol was aseptically added to molten $\mathrm{PDA}$ at $45^{\circ} \mathrm{C}$ in order to discourage bacterial growth. The microorganisms were isolated using the pour plate method. The serial dilution was used. About $1 \mathrm{~g}$ of each sample was added into test tubes containing $10 \mathrm{ml}$ sterile water and these served as stock solutions. About $1 \mathrm{ml}$ was aseptically removed from each of the stock solutions and added to another set of test tubes containing $9 \mathrm{ml}$ sterile water each to make $10^{-1}$ dilution. Similar transfers were repeated to make $10^{-2}$ decimal dilution. Thereafter, about $1 \mathrm{ml}$ of the $10^{-2}$ decimal dilution was introduced into sterile petri dishes and sterile molten agar was poured into the plates. The inoculated plates were allowed to set and incubated in an inverted position in order to avoid condensed water vapours on the plate cover from dropping on the culture. The NA (for bacterial culture) was incubated at $37^{\circ} \mathrm{C}$ for $24 \mathrm{~h}$ while the PDA plates (for fungal culture) were incubated at $25^{\circ} \mathrm{C}$ for $72 \mathrm{~h}$. Thereafter, the number of colonies found on each media after incubation were counted and expressed in $\log \mathrm{CFU} / \mathrm{g}$.

Textural characteristics of the popped pearl millet bar (PPMB) at regular gap of 30 days during 3 months storage period in terms of hardness and crispness were measured in triplicate using a Texture Analyzer (TAXT Plus, Stable Micro Systems, Surrey, UK) with compression probe and exponent TEE32 software (v.3.0.4.0).

Data analysis was performed using the statistical package of SPPS, v.16.0 with a probability of $P<0.05$. The data on chemical and sensory attributes were analysed using statistical parameters.

$100 \mathrm{~g}$ of pearl millet was equilibrated to a moisture content of $18 \%$ by adding water and tempered for $6 \mathrm{~h}$ in a closed container. The tempered grains were popped by high temperature and short time treatment (HTST) in a domestic grain popper (Nova popcorn maker NPC-1212) at $230 \pm 5^{\circ} \mathrm{C}$ (ref. 18). Puffing of amaranth was carried out by the method of Muyonga et al. ${ }^{19}$. The amaranth grains were puffed by heating in an iron pan without the use of sand as heating means. The temperature was maintained at approximately $220^{\circ} \mathrm{C}$ with stirring constantly by wooden ladle. The grains began to pop after heating for $30 \mathrm{sec}$. The grains after puffing were passed through a sieve to separate puffed and unpuffed grains. Flax seeds and sunflower seeds were toasted at a temperature of around $70^{\circ} \mathrm{C}$ until they turned to light brown colour.

Sugar syrup was prepared by direct heating the sugar on low heat at a temperature of about $45^{\circ} \mathrm{C}$ in an open pan. The sugar was continuously heated while stirring occasionally and the syrup was heated to $85^{\circ}$ Brix. The 
$\mathrm{CMC}$ was dissolved in warm water $\left(45-50^{\circ} \mathrm{C}\right)$ with continuous stirring and immediately added to the sugar syrup and mixed carefully.

To the hot syrup/binder, pre-heated $\left(50^{\circ} \mathrm{C}\right)$ dried mixture was added and the mixture was continuously stirred so that a homogeneous mixture could be obtained. The mixture was molded into non-stick stainless-steel rectangular mould having dimension of $10 \times 5 \times 1 \mathrm{~cm}$ with a serving size of $40 \mathrm{~g}$ and pressed with a wooden roller to obtain bars.

The developed bars were cooled at room temperature $\left(27^{\circ} \mathrm{C}\right)$, and packed in high density poly ethylene (HDPE) pouches and metalized pouches and stored under ambient temperature conditions (maximum temperature: $25.95 \pm$ $28.0^{\circ} \mathrm{C}$, minimum temperature: $17.6 \pm 12.1^{\circ} \mathrm{C}$ and relative humidity: $60 \pm 19 \%$ ) for 3 months.

Sensory evaluation of PPMB was carried out by the panel of trained judges (10 nos) on a 9-point Hedonic scale grading (from Like extremely to Dislike extremely), to evaluate the acceptability of product with respect to colour, taste, crunchiness and overall acceptability ${ }^{20}$.

Popping is a process that is widely used for making foods from cereals and millets. It is a type of starch cookery, where grains are exposed to high temperature for short time. Popping of millet grains invariably improves taste and flavour. It is one of the easiest and economic processing methods to develop ready-to-eat products. Popping essentially forms a crisp, aerated product with desirable sensory qualities. This is highly advantageous with respect to pearl millet, as unprocessed pearl millet has very low shelf life. The popping process not only improves the shelf life but also improves the nutritional quality with respect to bioavailability of nutrients ${ }^{18,21}$. In the present study, pearl millet was popped, and in three different ratios the bar was prepared to standardize the ingredient composition of the ready-to-eat bar product (Table 1).

The PPMB developed under different trials was evaluated for higher acceptability through panel of trained judges on a 9-point Hedonic scale. The resulted sensory scores are presented in Table 2. The bar developed from

Table 1. Recipe formulation for popped pearl millet bar

\begin{tabular}{lccc}
\hline & \multicolumn{3}{c}{ Recipe combination (g) } \\
\cline { 2 - 4 } Ingredients & B1 & B2 & B3 \\
\hline Popped pearl millet & 25 & 25 & 25 \\
Sugar & 40 & 40 & 40 \\
Roasted bengal gram & 10 & 10 & 12 \\
Sunflower seed & 4.0 & 3.0 & 3.0 \\
Flax seed & 2.5 & 3.0 & 2.0 \\
Popped amaranth & 15 & 15 & 15 \\
Raisins & 3.0 & 4.0 & 5.0 \\
Carboxy-methyl cellulose (CMC) & 0.5 & 1.0 & 1.0 \\
Total & 100 & 100 & 100 \\
\hline
\end{tabular}

PPMB was evaluated by sensorial analysis of acceptability. Three variants named B1, B2 and B3 were developed from the incorporation of whole popped pearl millets, each at $25 \%$. From the scores of all products for each attribute, it was clear that variant B3 was found to be most acceptable with an overall acceptability score of $8.7 \pm 0.12$ followed by B2 with an overall acceptability score of $8.00 \pm 0.79$. Variant B1 was third with a score of $7.66 \pm 0.14$. There was a non-significant difference $(P \geq 0.05)$ between these three variants for overall acceptability attribute. In terms of colour, B3 was preferred most followed by variants B2 and B1 respectively. B3 was again the most acceptable sample pertaining to attributes taste and crunchiness, followed by variants B2 and B1 in both cases. In conclusion, B3 was most the acceptable variant in terms of all sensory attributes compared to other two variants. Popping induces desirable aroma in snack based products which make them highly acceptable $^{22}$. Thus, B3 sample was used as a standardized product and selected for further studies.

Weight, diameter, width and bulk density were the different parameters of the developed bar which were evaluated and presented in Table 3 . The weight of the prepared PPMB was $40 \mathrm{~g}$ with $10 \times 5 \times 1 \mathrm{~cm}$ dimensions. The bulk density of the bar was $292.45 \mathrm{~kg} / \mathrm{m}^{3}$.

The data regarding nutrient composition of PPMB is given in Table 4. The moisture content in the prepared PPMB was found to be $1.10 \pm 0.03$, indicating low moisture content. Low value of moisture content indicates that these cereal bars can be stored for a long period of time without microbial spoilage ${ }^{23}$. The developed PPMB provided $412.2 \mathrm{Kcal}$ of energy per $100 \mathrm{~g}$, which qualified the product as an energy dense snack for sports persons also. Protein content of pearl millet bar was found to be $10.84 \%$. Similar result was reported in a study ${ }^{24}$ which obtained a protein content of $10.49 \%$. This higher protein content was as a result of incorporating pearl millet, amaranth and roasted bengal gram in the formulation. Another study $^{25}$ found $10.3 \%$ to $12.4 \%$ protein content of flax seed-enriched cereal bars. These bars consisted of $82.3 \mathrm{~g}$ carbohydrate and $4.39 \mathrm{~g}$ fat. One more research study ${ }^{26}$ reported a similar fat content in ladoo prepared from popped pearl millet and bengal gram. The total ash content of the bar in present study was $1.39 \pm 0.02 \mathrm{~g}$. The results of present study are comparable with earlier studies $^{25,27}$ where ash content $(0.97 \%$ to $1.88 \%)$ of the granolas/cereal bars formulated with Sunnah foods and puffed glutinous rice, where, particularly the ash content was $1.3 \%$ to $1.5 \%$ in flax seed enriched cereal bars. Another study on formulation of cereal bar with Agave tequilana ingredients found $0.95 \%$ to $1.05 \%$ ash content ${ }^{28}$.

The energy contribution of the developed PPMB was on par with the popped pearl millet ladoo developed in two different studies ${ }^{26,29}$. PPMB formed a good source of protein $(10.84 \mathrm{~g} / 100 \mathrm{~g})$, fat $(4.39 \mathrm{~g} / 100 \mathrm{~g})$ and carbohydrate $(82.3 \mathrm{~g} / 100 \mathrm{~g})$ (Table 4$)$. The results of this study 


\section{RESEARCH COMMUNICATIONS}

Table 2. Sensory evaluation of popped pearl millet bar

\begin{tabular}{lrrrr}
\hline Formulation & Colour & Taste & Crunchiness & Overall acceptability \\
\hline B1 & $7.52 \pm 0.14^{\mathrm{a}}$ & $7.01 \pm 0.12^{\mathrm{b}}$ & $7.42 \pm 0.18^{\mathrm{a}}$ & $7.66 \pm 0.14^{\mathrm{a}}$ \\
B2 & $7.7 \pm 0.73^{\mathrm{a}}$ & $7.4 \pm 0.85^{\mathrm{a}}$ & $7.6 \pm 0.83^{\mathrm{a}}$ & $8.0 \pm 0.79^{\mathrm{a}}$ \\
B3 & $8.84 \pm 0.13^{\mathrm{a}}$ & $9.0 \pm 0.11^{\mathrm{a}}$ & $8.8 \pm 0.32^{\mathrm{a}}$ & $8.7 \pm 0.12^{\mathrm{a}}$ \\
\hline
\end{tabular}

PPMB with $25 \%$ popped pearl millet. Values are mean \pm SE of thirty panellists. Means followed by different superscripts in a column differ statistically significantly at $P<0.05$.

Table 3. Physical characteristics of popped pearl millet bar

\begin{tabular}{lc}
\hline Physical parameter & Value \\
\hline Weight $(\mathrm{g})$ & 40 \\
Length $(\mathrm{cm})$ & 10 \\
Width $(\mathrm{cm})$ & 5 \\
Bulk density $\left(\mathrm{kg} / \mathrm{m}^{3}\right)$ & 292.45 \\
\hline
\end{tabular}

Table 4. Nutrient composition of popped pearl millet bar

\begin{tabular}{lc}
\hline Component & Popped pearl millet bar \\
\hline Moisture $(\mathrm{g} / 100 \mathrm{~g})$ & $1.10 \pm 0.03$ \\
Ash $(\mathrm{g} / 100 \mathrm{~g})$ & $1.39 \pm 0.02$ \\
Protein $(\mathrm{g} / 100 \mathrm{~g})$ & $10.84 \pm 0.05$ \\
Total fat $(\mathrm{g} / 100 \mathrm{~g})$ & $4.39 \pm 0.12$ \\
Crude fibre $(\mathrm{g} / 100 \mathrm{~g})$ & 0.09 \\
Carbohydrate $(\mathrm{g} / 100 \mathrm{~g})$ & $82.35 \pm 0.11$ \\
Energy value $(\mathrm{Kcal} / 100 \mathrm{~g})$ & $412.2 \pm 0.03$ \\
Calcium $(\mathrm{mg} / 100 \mathrm{~g})$ & $58.70 \pm 0.73$ \\
Phosphorus $(\mathrm{mg} / 100 \mathrm{~g})$ & $215.65 \pm 0.37$ \\
Iron $(\mathrm{mg} / 100 \mathrm{~g})$ & $3.17 \pm 0.02$ \\
Zinc $(\mathrm{mg} / 100 \mathrm{~g})$ & $5.13 \pm 0.01$ \\
Niacin $(\mathrm{g} / 100 \mathrm{~g})$ & $0.47 \pm 0.01$ \\
Folic acid $(\mathrm{g} / 100 \mathrm{~g})$ & $0.30 \pm 0.01$ \\
Vitamin E $(\mathrm{g} / 100 \mathrm{~g})$ & $0.38 \pm 0.02$ \\
Dietary fibre $(\mathrm{g} / 100 \mathrm{~g})$ & $6.45 \pm 0.04$ \\
\hline Values &
\end{tabular}

Values are mean \pm SD of three replicates.

showed that the inclusion of puffed amaranth, flax seed and sunflower seed in pearl millet bar were helpful in increasing the nutrient content specially the protein content. Hence this can be helpful in alleviating protein deficiency diseases among children.

The developed PPMB was rich in minerals and contained $58.70 \mathrm{mg} / 100 \mathrm{~g}$ calcium, $215.65 \mathrm{mg} / 100 \mathrm{~g}$ phosphorus, $5.13 \mathrm{mg} / 100 \mathrm{~g}$ zinc and $3.17 \mathrm{mg} / 100 \mathrm{~g}$ iron respectively (Table 4 ). This pattern of high mineral content in the popped bar might be due to the available high mineral content in pearl millet. These findings are in close agreement with the findings of earlier studies. In a study on snack bar developed from sorghum flakes, it was found that the mineral content like iron, zinc, manganese, copper and calcium were 4.47, 0.27, 0.09, $0.23 \mathrm{ppm}$ and $37.92 \mathrm{mg}$ per $100 \mathrm{~g}$ respectively ${ }^{30}$. Similarly, another study ${ }^{31}$ reported increased calcium, iron and zinc content in 13 different traditional products. A study reported that the protein rich sorghum bar had good amount of calcium, iron and zinc and suggested that these cereal bars could be included in the supplementary nutrition programmes like Integrated Child Development Services (ICDS) and Mid-Day Meal programme for alleviating protein energy deficiency problem in malnourished children ${ }^{32}$. The PPMB contained $0.47 \mathrm{mg} / 100 \mathrm{~g}$ Niacin, $0.30 \mathrm{mg} / 100 \mathrm{~g}$ Folic Acid and $0.38 \mathrm{mg} / 100 \mathrm{~g}$ Vitamin E respectively.

The level of dietary fibre was found to be $6.45 \mathrm{~g} / 100 \mathrm{~g}$, since the dietary fibre content in pearl millet ranged between $8 \%$ to $9 \%$ (ref. 33). In a study (2010), snack bars containing high dietary fibre (DF) and polyphenol contents were developed. Snack bar base was formulated with or without the use of apple polyphenol extract (APE). Results of the study showed that snack bars with added APE gave the highest amount of total DF $(5.3 \%$ $\mathrm{w} / \mathrm{w})^{34}$. However, in another study on sorghum flakesbased snack bar, the total dietary fibre, insoluble dietary fibre and soluble dietary fibre ranged from $10.13 \%$, $7.63 \%$ and $2.50 \%$ respectively ${ }^{30}$.

Moisture content has an important role in determining the storage life of any food product. Generally, moisture content decreases or increases during storage depending upon the storage condition and packaging material. In the present study, during the storage period of 0 to 90 days the moisture content increased from $4.87 \%$ to $5.79 \%$ in HDPE pouch, and $3.37 \%$ to $4.46 \%$ in MP pouch respectively (Table 5) by the end of 3 months ( 90 days). This could be due to the fact that MP pouch has better barrier properties compared to HDPE. The results showed that the moisture content $(<12 \%)$ of the bar packed in metalized packaging material was within the permissible limit throughout the storage period. Earlier studies reported that increasing the storage period of flax oat nutty bar was responsible for increased moisture uptakes ${ }^{24}$ as well as increased moisture content of oat bars during storage $^{24,25}$. Another study reported increased moisture content in wild apricot fruit bar from $18.89 \%$ to $20.39 \%$ and $20.12 \%$ in polyethylene and laminated pouches respectively, that were stored for 6 months ${ }^{35}$. Similarly, an increase in moisture was reported in a study ${ }^{9}$ on protein rich compressed bar packed in cellophane followed by paper (40 GSM), aluminium foil $(0.02 \mu)$ and polyethylene $(37 \mu$ ) (from $3.83 \%$ to $5.21 \%$ ), stored at ambient temperature for 14 months. Two different studies on shelf life also showed increased moisture content of extruded snacks during storage ${ }^{36,37}$. 
Table 5. Change in chemical constituents during storage of popped pearl millet bar

\begin{tabular}{|c|c|c|c|c|c|c|c|c|}
\hline \multirow[b]{2}{*}{ Attribute } & \multirow{2}{*}{$\begin{array}{c}\text { Packaging } \\
\text { material }\end{array}$} & \multicolumn{7}{|c|}{ Storage period (days) } \\
\hline & & 0 & 15 & 30 & 45 & 60 & 75 & 90 \\
\hline \multirow[t]{2}{*}{ Moisture } & HDPE & $4.87 \pm 0.07$ & $5.06 \pm 0.07$ & $5.22 \pm 0.06$ & $5.38 \pm 0.06$ & $5.57 \pm 0.07$ & $5.66 \pm 0.07$ & $5.79 \pm 0.07$ \\
\hline & MP & $3.37 \pm 0.05$ & $3.45 \pm 0.05$ & $3.67 \pm 0.01$ & $3.89 \pm 0.05$ & $4.08 \pm 0.05$ & $4.23 \pm 0.01$ & $4.46 \pm 0.01$ \\
\hline \multirow[t]{2}{*}{ Water activity $\left(a_{\mathrm{w}}\right)$} & HDPE & $0.16 \pm 0.001$ & $0.28 \pm 0.001$ & $0.30 \pm 0.001$ & $0.33 \pm 0.001$ & $0.39 \pm 0.001$ & $0.44 \pm 0.001$ & $0.51 \pm 0.001$ \\
\hline & MP & $0.16 \pm 0.001$ & $0.17 \pm 0.001$ & $0.18 \pm 0.001$ & $0.26 \pm 0.001$ & $0.30 \pm 0.001$ & $0.38 \pm 0.002$ & $0.42 \pm 0.001$ \\
\hline \multirow[t]{2}{*}{ Peroxide value } & HDPE & $0.40 \pm 0.32$ & $0.68 \pm 0.31$ & $0.98 \pm 0.28$ & $1.41 \pm 0.29$ & $1.66 \pm 0.30$ & $1.78 \pm 0.31$ & $2.00 \pm 0.36$ \\
\hline & MP & $0.40 \pm 0.32$ & $0.56 \pm 0.20$ & $0.81 \pm 0.21$ & $1.00 \pm 0.22$ & $1.23 \pm 0.22$ & $1.39 \pm 0.23$ & $1.53 \pm 0.25$ \\
\hline \multirow[t]{2}{*}{ Free fatty acids } & HDPE & $0.52 \pm 0.01$ & $0.63 \pm 0.01$ & $0.74 \pm 0.02$ & $0.75 \pm 0.02$ & $0.76 \pm 0.02$ & $0.77 \pm 0.01$ & $0.79 \pm 0.01$ \\
\hline & MP & $0.52 \pm 0.01$ & $0.63 \pm 0.01$ & $0.54 \pm 0.01$ & $0.56 \pm 0.02$ & $0.58 \pm 0.02$ & $0.61 \pm 0.03$ & $0.62 \pm 0.02$ \\
\hline
\end{tabular}

Values are mean \pm SD of three replicates.

Table 6. Microbial quality of popped pearl millet bar during storage

\begin{tabular}{|c|c|c|c|c|c|c|c|c|c|c|c|c|c|c|}
\hline \multirow{3}{*}{$\begin{array}{l}\text { Packaging material } \\
\text { Days }\end{array}$} & \multicolumn{7}{|c|}{ Total plate count $(\log \mathrm{CFU} / \mathrm{g})$} & \multicolumn{7}{|c|}{ Yeast/mold count (log CFU/g) } \\
\hline & \multicolumn{7}{|c|}{ Storage at ambient condition } & \multicolumn{7}{|c|}{ Storage at ambient condition } \\
\hline & 0 & 15 & 30 & 45 & 60 & 75 & 90 & 0 & 15 & 30 & 45 & 60 & 75 & 90 \\
\hline HDPE & ND & ND & ND & 2.74 & 2.85 & 2.96 & 3.04 & ND & ND & ND & ND & ND & ND & ND \\
\hline MP & ND & ND & ND & ND & 1.60 & 1.84 & 1.91 & ND & ND & ND & ND & ND & ND & ND \\
\hline
\end{tabular}

The changes in water activity $\left(a_{\mathrm{w}}\right)$ of the PPMB packed in two different packaging materials, i.e. HDPE and MP during the storage period are given in Table 5. It was found that the water activity of the bar in HDPE packaging ranged from 0.165 to 0.57 , and 0.165 to 0.42 in MP packaging during 3 months storage period. Cereal bars are generally formulated to have moisture between $10 \%$ and $15 \%(\mathrm{w} / \mathrm{w})$ and $a_{\mathrm{w}}$ values less than 0.65 (ref. 38). This means that in the present study, PPMB stored in MP pouch was within the safe level for water activity. Probiotic millet bars formulated from puffed pearl millet including other ingredients in an earlier investigation, found that the bars had safe limits due to low water activity $\left(a_{\mathrm{w}}=0.58\right)$ which was in agreement with the earlier study $^{39}$. On overall evaluation of storage period, we found that the formation of free fatty acids was lower in case of pearl millet bar stored in MP as compared to HDPE, due to good oxygen barrier property of MP. The reason for increased free fatty acids during storage is due to oxidation and hydrolysis of fat content in raw materials and action of moisture and storage temperature. Increase in free fatty acids during storage of protein rich composite cereal bars has been reported earlier ${ }^{24}$.

A significant increase was noticed in the peroxide value of PPMB during storage in both HDPE and MP (Table 5). On overall evaluation of storage period, it was found that the formation of peroxides was higher in case of bars stored in HDPE compared to MP. Peroxide value gave a measure of the extent to formation of hydroperoxides during fat oxidation. The increase was less in MP due to good oxygen barrier property of aluminium laminates.
The peroxide value of PPMB increased from $0.40 \%$ to $1.53 \%$ in MP and from $0.40 \%$ to $2.00 \%$ in HDPE during 90 days storage period. Another study also reported increase in peroxide value during storage of protein rich composite cereal bars $^{24}$.

The result of microbial load of PPMB at different intervals is given in Table 6 . The microbial analysis was done at different periodic intervals, and until the storage for 90 days, no microbial load was indicated in MP packaging. However, it was observed in HDPE after 45 days of storage itself, i.e. $2.85 \log \mathrm{CFU} / \mathrm{g}$. Highest TPC was observed in HDPE pouch bar on 90 days of storage, whereas, least TPC growth was found in MP packed bar. Both packaged bars remained safe during the 90 days period. The microbial load of the bar was found to be below detectable limits $(<50,000 \mathrm{cfu} / \mathrm{g})$ according to Prevention of Food Adulteration Act (1954). Moreover, yeast and mold growth was not observed in all stored samples. These findings showed that the developed bars were acceptable and their contamination level was minimum, hence, it could be concluded that the developed product is safe from consumer point of view. This indicates that the developed bar is consumable and safe for consumers till 3 months storage period. The above findings of our study might be possible due to development of product under hygienic conditions, baking at adequate temperature and low oxygen and moisture transmission rate of packaging materials. Another study reported that the developed composite cereal bar during 9 months of storage remained microbiologically stable and acceptable $^{24}$. Similar observation was recorded by previous 


\section{RESEARCH COMMUNICATIONS}

Table 7. Effect of storage period on hardness (N) of popped pearl millet bar

\begin{tabular}{lcc}
\hline Storage period (days) & Packaging material I (HDPE) & Packaging material II (MP) \\
\hline 0 & $78.39 \pm 1.77^{\mathrm{a}}$ & $78.35 \pm 3.91^{\mathrm{a}}$ \\
30 & $76.91 \pm 1.77^{\mathrm{ab}}$ & $73.33 \pm 3.91^{\mathrm{a}}$ \\
60 & $72.23 \pm 1.86^{\mathrm{b}}$ & $56.27 \pm 4.10^{\mathrm{b}}$ \\
90 & $30.86 \pm 1.86^{\mathrm{c}}$ & $53.28 \pm 4.10^{\mathrm{b}}$ \\
\hline Values are mean \pm standard error of three replications. Mean in the same rows followed by same
\end{tabular}

Values are mean $t$ standard error of three replications. Mean in the same rows followed by same superscript letter are not differed significantly at $P \leq 0.05$.

Table 8. Effect of storage period on crispness of popped pearl millet bar

\begin{tabular}{lcc}
\hline Storage period (days) & Packaging material I (HDPE) & Packaging material II (MP) \\
\hline 0 & $113.00 \pm 2.35^{\mathrm{a}}$ & $113.00 \pm 2.58^{\mathrm{a}}$ \\
30 & $81.00 \pm 2.45^{\mathrm{b}}$ & $106.00 \pm 2.77^{\mathrm{a}}$ \\
60 & $60.33 \pm 2.45^{\mathrm{b}}$ & $76.33 \pm 2.77^{\mathrm{b}}$ \\
90 & $44.67 \pm 2.45^{\mathrm{c}}$ & $63.33 \pm 2.77^{\mathrm{c}}$ \\
\hline Values are mean + standard error of three replions. Mean in the same rows followed by same
\end{tabular}

superscript letter are not differed significantly at $P \leq 0.05$

scientists who found that the total bacterial count $(\log$ $\mathrm{cfu} / \mathrm{g}$ ) in flax seed enriched bar increased from 3.4 to 4.7 during 90 days storage ${ }^{40}$.

The storage life of a product can be defined as the length of time that a product can be stored before the appearance of the first characteristic that consumers find unacceptable ${ }^{38}$. Chemical and physical changes among the ingredients in bars can occur over time and begin to affect the texture of the product. Thus, in the present study, texture of bar was found significantly affected during storage both in MP and HDPE packaging.

Hardness of cereal bar was found significantly affected during storage both in MP pouch and HDPE pouch as presented in Table 7. Hardness (N) was the peak force that occurred during first compression. Results indicated that hardness decreased with increasing moisture content. The hardness decreased from 78.39 to $30.86 \mathrm{~N}$ in HDPE, and from 78.35 to 53.28 in MP. Thus, significant variation was noticed in the hardness of cereal bar during storage in both packaging materials (Table 7). However, hardness decreased drastically in pearl millet bar stored in HDPE indicating that this packaging material is not suitable for storage. A previous study reported that the texture significantly $(P \leq 0.05)$ affected the acceptability and preference of the samples, while other parameters were found to be non-significant $(P \leq 0.05)$ among the cereal bar samples ${ }^{25}$. It was found that the MP packaging was suitable for storage of PPMB.

Popped Pearl Millet Bar (PPMB) samples packed in MP and HDPE packaging were used to study the changes in their crispness. Obtained observations are presented in Table 8. There was significant decrease in crispness during storage as presented in the above table. In freshly prepared bar, crispness was same in both the packaging materials, i.e. 113 on 0 day. After that, it decreased to 44.67 in HDPE and 63.27 in MP after 3 months of sto- rage. The interaction of packaging materials and storage period was found to be significant for crispness. An earlier study reported decrease in crispness of bayberry fruit bar during storage ${ }^{41}$. Since the textural profile in the present study had no significant change and was found to be acceptable during storage period of 90 days in MP pouch, thus indicating its suitability for commercialization.

Changes in sensory attributes like colour, aroma, taste, texture and overall acceptability on a 9-point Hedonic scale (where 9 was given for excellent in all respects and 1 for highly disliked samples) at ambient temperature and $37^{\circ} \mathrm{C}$ are given in Table 9. From the data, it is observed that there was a gradual but significant $(P \leq 0.05)$ decrease in all the sensory attributes during storage in HDPE pouch. However, crunchiness of the bar deteriorated at much faster rate which ranged from 8.00 in the beginning and decreased to 6.60 in HDPE than 7.65 in MP after 90 days storage period, on a 9-point Hedonic scale at ambient temperature $\left(25 \pm 28^{\circ} \mathrm{C}\right)$. The pearl millet bar was found to be in better taste, scoring 7.70 at the start of storage which decreased to 5.11 in HDPE and 7.08 in MP at the end of 90 days. However, the bar was slightly bitter in taste in HDPE during storage. This led to the decline in taste scores during storage (Table 9). A study on storage of papaya fruit bar also reported decrease in taste scores during storage in polyethylene and laminates ${ }^{42}$. A study on storage of sorghum flake bar reported that there was no significant change in colour, taste, flavour and overall acceptability score of sorghum flake bar throughout the storage period of 3 months ${ }^{33}$.

The overall acceptability decreased non-significantly during the storage of PPMB as depicted in Table 9. The samples on an average scored 8.02 at the beginning which decreased to 6.23 in HDPE and 7.47 in MP. Colour, taste and overall acceptability were found to be 
RESEARCH COMMUNICATIONS

Table 9. Sensory evaluation of popped pearl millet bar

\begin{tabular}{|c|c|c|c|c|c|c|c|}
\hline Days & 0 & 15 & 30 & 45 & 60 & 75 & 90 \\
\hline \multicolumn{8}{|l|}{ Colour } \\
\hline HDPE & $8.10 \pm 0.17$ & $8.10 \pm 0.10$ & $8.00 \pm 0.00$ & $8.00 \pm 0.21$ & $7.70 \pm 0.21$ & $7.40 \pm 0.22$ & $6.90 \pm 0.20$ \\
\hline MP & $8.10 \pm 0.10$ & $8.10 \pm 0.17$ & $8.00 \pm 0.00$ & $8.00 \pm 0.21$ & $7.80 \pm 0.13$ & $7.66 \pm 0.22$ & $7.54 \pm 0.22$ \\
\hline \multicolumn{8}{|l|}{ Taste } \\
\hline HDPE & $7.70 \pm 0.26$ & $7.70 \pm 0.15$ & $7.60 \pm 0.22$ & $7.40 \pm 0.22$ & $6.80 \pm 0.13$ & $5.89 \pm 0.13$ & $5.11 \pm 0.05$ \\
\hline MP & $8.00 \pm 0.25$ & $8.00 \pm 0.00$ & $8.00 \pm 0.21$ & $7.80 \pm 0.24$ & $7.72 \pm 0.37$ & $7.67 \pm 0.38$ & $7.51 \pm 0.21$ \\
\hline \multicolumn{8}{|c|}{ Crunchiness } \\
\hline HDPE & $8.00 \pm 0.25$ & $8.00 \pm 0.22$ & $7.80 \pm 0.13$ & $7.60 \pm 0.16$ & $7.20 \pm 0.38$ & $7.00 \pm 0.21$ & $6.60 \pm 0.26$ \\
\hline MP & $8.00 \pm 0.00$ & $8.00 \pm 0.21$ & $7.90 \pm 0.15$ & $7.81 \pm 0.37$ & $7.76 \pm 0.37$ & $7.70 \pm 0.21$ & $7.65 \pm 0.15$ \\
\hline \multicolumn{8}{|c|}{ Overall acceptability } \\
\hline HDPE & $8.04 \pm 0.15$ & $7.74 \pm 0.12$ & $7.05 \pm 0.14$ & $6.73 \pm 0.42$ & $6.66 \pm 0.34$ & $6.40 \pm 0.18$ & $6.23 \pm 0.09$ \\
\hline MP & $8.04 \pm 0.14$ & $8.04 \pm 0.12$ & $7.94 \pm 0.09$ & $7.89 \pm 0.24$ & $7.77 \pm 0.25$ & $7.70 \pm 0.25$ & $7.65 \pm 0.17$ \\
\hline
\end{tabular}

Values are mean \pm SD of 10 panelists.

highest in MP packaging compared to HDPE packaging material. Similar observation was recorded in the study of wild apricot bar; it was found that the overall acceptability decreased from 7.84 to 7.40 and 7.54 for product packed in polyethylene and aluminium laminate pouch respectively during 6 months of storage ${ }^{35}$. Decreased overall acceptability score of papaya fruit bars during storage in polyethylene and laminates has been reported ${ }^{42}$. Study on storage of three types of multigrain bars packed in MP pouch found maximum overall acceptability scores during storage, whereas, HDPE packed sample had least acceptability during storage. These bars during storage became softer and adversely influenced the overall acceptability scores and hence shelf-life ${ }^{43}$.

The present study focused to explore the nourishing potential of pearl millet as well as development of a novel food product with cost effectiveness. The bar was prepared by heating, mixing and cooling popped pearl millet, popped amaranth, puffed bengal gram, flax seeds, sunflower seeds, raisins, and sugar. The study revealed that the popping process increased nutrients significantly such as protein, iron, zinc and calcium; the bar is highly acceptable, easy to digest and has good potential to fight malnutrition in children. Sensory evaluation of PPMB revealed that it possessed good sensory attributes in terms of colour, flavour, taste, appearance, and overall taste which showed acceptable level. The developed PPMB has a shelf life of 3 months. Therefore, it could be concluded that the pearl millet grain has a wide range of opportunity for utilization in development of ready-to-eat, nutritionally rich bar along with better sensory attributes, which, on a commercial scale may open new avenues for better utilization and marketing of this important yet underutilized grain.

1. Satyavathi, C. T., Praveen, S., Mazumdar, S., Chugh, L. K. and Kawatra, A., Enhancing demand of pearl millet as super graincurrent status and way forward. ICAR-All India Coordinated Research Project on Pearl Millet, Jodhpur, 2017.

2. Onyango, C. A., Ochanda, S. O., Mwasaru, M. A., Ochieng, J. K., Mathooko, F. M. and Kinyuru, J. N., Effects of malting and fer- mentation on anti-nutrient reduction and protein digestibility of red sorghum, white sorghum and pearl millet. J. Food Res., 2013, 2(1), 41-49.

3. Sade, F. O., Proximate, anti-nutritional factors and functional properties of processed pearl millet (Pennisetum glaucum). J. Food Technol., 2009, 7(3), 92-97.

4. Malleshi, N. G. and Desikachar, H. S. R., Varietal difference in puffing quality of ragi (Eleusine coracana). J. Food Sci. Technol., 1981, 18, 30-32.

5. Mariott, M., Alamprese, C., Pagani, M. A. and Lucisano, M., Effect of puffing on ultrastructure and physical characteristics of cereal grains and flours. J. Cereal Sci., 2006, 43(1), 47-56.

6. Kumari, R., Singh, K., Jha, S. K., Singh, R., Sarkar, S. K. and Bhatia, N., Nutritional composition and popping characteristics of some selected varieties of pearl millet (Pennisetum glaucum). Indian J. Agric. Sci., 2018, 88(8), 344-348.

7. Giri, N. A., Taur, A. T., Kshirsagar, R. B. and Yadav, G. B., Studies on formulation and evaluation of fiber rich food bars. Indian J. Nutr. Dietet., 2012, 49, 243-247.

8. Lobato, L. P., et al., Snack bars with high soy protein and isoflavone content for use in diets to control dyslipidaemia. Int. J. Food Sci. Nutr., 2011, 63, 1-10.

9. Sharma, G. K., Padmashree, A., Roopa, N. and Bawa, A. S., Storage stability of protein rich compressed bar. J. Food Sci. Technol., 2006, 43(4), 404-406.

10. Kumari, R., Singh, K., Singh, R. and Nain, M. S., Development of healthy RTE - breakfast cereal from popped pearl millet. Indian J. Agric. Sci., 2019, 89(5), 129-133.

11. AOAC. Official methods of the Association of Official Agricultural Chemists, Washington, DC, USA, 2000, 11th edn.

12. AOAC. Vitamin assays, Turbidimetric Method. AOAC Official Method, 2005, 960.46.

13. AOAC. Niacin and niacinamide (nicotinic acid and nicotinamide) in ready-to-feed milk-based infant formula microbiologicalturbidimetric method. AOAC Official Method, 2005, 985.34.

14. AACC. The definition of dietary fibre. Report of the dietary fibre definition committee to the board of directors of the American Association of Cereal Chemists. Cereal Food World, 2011, 46, $112-126$.

15. AOAC. Total, soluble, and insoluble dietary fiber in foods, enzymatic-gravimetric method, 2005.

16. Syed, H. M., Syed, I., Deshpande, H. W., Kulkarni, K. D. and Kulkarni, D. N., Chemical Analysis of Food Samples - Laboratory Manual, Needs Agencies, Parbhani (M.S.), India, 2007.

17. Olunlade, B. A., Adeola, A. A. and Anuoluwapo, A. O., Microbial profile of maize-pigeon pea biscuit in storage. Fountain J. Nat. Appl. Sci., 2013, 2, 1-9.

18. Pradeep, P. M., Dharmaraj, U., Sathyendra Rao, B. V., Senthil, A., Vijayalakshmi, N. S., Malleshi, N. G. and Singh, V., Formulation 
and nutritional evaluation of multigrain ready-to-eat snack mix from minor cereals. J. Food Sci. Technol., 2013, 51(12), 38123820 .

19. Muyonga, J. H., Andabati, B. and Ssepuuya, G., Effect of heat processing on selected grain amaranth physicochemical properties. Food Sci. Nutr., 2014, 2(1), 9-16.

20. Obatolu, V. A., Omucti, C. O. and Ebenerer, A. A., Qualities of extruded puffed snacks from maize/soybean mixture. J. Food Process Eng., 2016, 29, 149-161.

21. Mishra, G., Joshi, D. C. and Panda, B. K., Popping and puffing of cereal grains: a review. J. Grain Process. Storage, 2014, 1, 34-46.

22. Bunkar, D. S., Jha, A. and Mahajan, A., Optimization of the formulation and technology of pearl millet based 'ready-toreconstitute' kheer mix powder. J. Food Sci. Technol., 2012, 51, 2404-2414.

23. Oloyede, O. I., Chemical profile of unripe pulp of carica papaya Pak. J. Nutr., 2005, 4(6), 379-381.

24. Padmashree, A., Sharma, G. K. and Govindaraj, G., Development and evaluation of shelf stability of flaxoat nutty bar in different packaging materials. Food Nutr. Sci., 2013, 4, 538-546.

25. Mridula, K. K. and Singh, P., Barnwal development of Omega-3 rich energy bar with flaxseed. J. Food Sci. Technol., 2013, 50(5), 950-957.

26. Singh, G., Development of value-added products from pearl millet, Ph.D. thesis, Chaudhary Charan Singh Haryana Agricultural University, Hisar, Haryana, 2005.

27. Agbaje, R., Hassan, C. Z., Norlelawati, A., Rahman, A. and Huda, F. N., Development and physico-chemical analysis of granola formulated with puffed glutinous rice and selected dried sunnah foods. Int. Food Res. J., 2016, 23(2), 498-506.

28. Zamora-Gasga, V. M., Bello-Perez, L. A., Ortiz-Basurto, R. I., Tovar, J. and Sayago-Ayerdi, S. G., Granola bars prepared with Agave tequilana ingredients: chemical composition and in vitro starch hydrolysis. Food Sci. Technol., 2014, 56(2), 309-314.

29. Sharma, M., Mridula, D., Yadav, D. N. and Gupta, R. K., Physiochemical characteristics of maize and sorghum as affected by popping. Proc. Natl. Acad. Sci. India, Sect. B. Biol. Sci., 2015, 85(3), 794-799.

30. Ribnar, A. A., Designing sorghum (Designing Sorghum (Sorghum bicolor (L.) Moench) flakes-based snack bar for nutritional and health benefits of children, M.Sc. thesis, University of Agricultural Sciences, Dharwad, 2014.

31. Tibagonzeka, J., Wambete, J., Muyinda, A. M., Nakimbugwe, D. and Muyonga, J. H., Acceptability and nutritional contribution of grain amaranth recipes in Uganda. Afr. J. Food Agric. Nutr. Dev., 2014, 14(3), 8979-8997.

32. Verma, S., Khetrapaul, N. and Verma, V., Development and standardisation of protein rich sorghum based cereal bars. Int. J. Curr. Microbiol. App. Sci., 2018, 7(5), 2842-2849.

33. Taylor, J. R. N., Millet: Pearl. Encycl. Grain Sci., 2004, 2, $253-$ 261.

34. Dongxiao, S.-W., Teoh, A., Massarotto, C. and Wibisono, R., Comparative analysis of fruit-based functional bars. Food Chem., 2010, 119(4), 1369-1379.

35. Sharma, S. K., Chaudhary, S. P., Rao, V. K., Yadav, V. K. and Bisht, T. S., Standardization of technology for preparation and storage of wild apricot fruit bar. J. Food Sci. Technol., 2013, 50(4), 784-790.

36. Manthey, F. A., Sinha, S., Wolf-Hall, C. E. and Hall, C. A., Effect of flaxseed flour and packaging on shelf life of refrigerated pasta. J. Food Process. Preserv., 2008, 32(1), 75-87.

37. Hiremath, S. P., Physio-chemical characteristics of raw, malted and popped finger millet varieties, M.Sc. thesis, University of Agricultural Sciences, GKVK, Bengaluru, 2011.

38. Loveday, S. M., Hindmarsh, J. P., Creamer, L. K. and Singh, H., Physicochemical changes in a model protein bar during storage. Food Res. Int., 2009, 42(7), 798-806.
39. Kavitha, B., Vijayalakshmi, R., Yalagala, P. C. R., Illamaran, M. and Sugasini, D., Nutritional evaluation and cell viability of formulated probiotic millet fruit bar. J. Food Nutr. Disor., 2018, 7.

40. Muhammad, N., Rehman, S., Muhammad, A. F., Anjum, M. M. and Din Ghulam, M., Development, characterization, and optimization of protein level in date bars using response surface methodology. Sci. World J., 2012, 2012, 10; https://doi.org/10.1100/ 2012/518702.

41. Yang, Z. F., Zheng, Y. H., Cao, S. F., Tang, S. S., Ma, S. J. and $\mathrm{Li}, \mathrm{N}$., Effects of storage temperature on textural properties of Chinese bay berry fruit. J. Texture Stud., 2007, 38(1), 166-177.

42. Aggarwal, P. and Kaur, R. P., Development of intermediate moisture product from carrot pulp. Am. J. Food Sci. Nutr. Res., 2014, 1, 52-59.

43. Marotirao, P. C., Development of process technology for nutritional multigrain bar and storage studies, M.Tech. (Food Sci.) Thesis. Vasantrao Naik Marathwada Agricultural University, Parbhani, Maharashtra, 2017.

ACKNOWLEDGEMENTS. The authors are thankful to ICAR-IARI and KVK Ujwa, New Delhi for providing the necessary support and facilities for conducting the present investigation. The free and fair response provided by the panel judges is duly acknowledged.

Received 16 July 2020; revised accepted 22 January 2021

doi: $10.18520 / \mathrm{cs} / \mathrm{v} 120 / \mathrm{i} 8 / 1374-1381$

\section{Insights into the petrogenesis of depleted mantle dunite from the central part of the Nagaland-Manipur Ophiolites, North East India}

\author{
A. Krishnakanta Singh ${ }^{1, *}$, S. Khogenkumar ${ }^{2}$, \\ Santosh Kumar ${ }^{3}$, L. Romendro Singh ${ }^{4}$ and \\ S. S. Thakur ${ }^{1}$ \\ ${ }^{1}$ Wadia Institute of Himalayan Geology, Dehradun 248 001, India \\ ${ }^{2}$ National Centre for Polar and Ocean Research, Goa 403 804, India \\ ${ }^{3}$ Department of Geology, Kumaun University, Nainital 263 002, India \\ ${ }^{4}$ Department of Geology, Thoubal College, Thoubal 795 138, India
}

This communication presents results of mineral and whole-rock geochemistry of rarely occurred dunites in the central part of the Nagaland-Manipur Ophiolites (NMO), North East India, and discusses their genesis and tectonic evolution. These rocks are characterized by low concentration of average $\mathrm{CaO}(0.58 \mathrm{wt} \%)$, $\mathrm{Al}_{2} \mathrm{O}_{3}(0.42 \mathrm{wt} \%)$ and $\Sigma$ REE (1.24 ppm), but high Mg\# (0.91-0.92) and $\mathrm{Cr} \#(0.61-0.73)$ values in chromian spinels. They exhibit a U-shaped REE pattern depleted in MREEs, which is equivalent to dunite

*For correspondence. (e-mail: aksingh_wihg@rediffmail.com) 